\title{
Tissue window, not the time window, will guide acute stroke treatment
}

\author{
David Wang, ${ }^{1,2}$ Yongjun Wang ${ }^{3,4}$
}

To cite: Wang D, Wang Y. Tissue window, not the time window, will guide acute stroke treatment. Stroke and Vascular Neurology 2019;4: e000211. doi:10.1136/svn-2018-000211

Received 8 November 2018 Accepted 14 November 2018 Published Online First 11 February 2019

\section{Check for updates}

(c) Author(s) (or their employer(s)) 2019. Re-use permitted under CC BY-NC. No commercial re-use. See rights and permissions. Published by BMJ.

${ }^{1}$ Chinese Stroke Association, Beijing, China

${ }^{2}$ Neurology, University of Illinois College of Medicine at Peoria,

Peoria, IL, USA

${ }^{3}$ China National Clinical

Research Center for

Neurological Disease, Beijing,

China

${ }^{4}$ Neurology, Tiantan Clinical Trial and Research Center for Stroke, Beijing, China

Correspondence to Professor David Wang; david.wang@chinastroke.net
Since the approval of intravenous (IV) tissue plasminogen activator (tPA) to treat patients with acute ischaemic stroke (AIS) within 3 hours of onset in 1996, it took 12 years to expand the treatment time window to 4.5 hours by the European Cooperative Acute Stroke Trial II (ECASS III). ${ }^{1}$ It took another 10 years to expand the treatment time window to 6 hours with the bridging of IV tPA and intra-arterial (IA) thrombectomy. ${ }^{2}$ In 2018, 22 years later after the approval of IV tPA and less than 3 years from the approval of IA thrombectomy, we have learnt that IA thrombectomy was effective in treating patients with AIS from large vessel occlusion (LVO) type of stroke up to 24 hours. ${ }^{3}$ This continued expansion of the treatment time window has brought hope to many patients with stroke who will present to the emergency room at a later time. It has also shattered our belief that poststroke ischaemic penumbra would only exist for a very brief time. The evidence lies in the multimodal imaging studies that can detect a penumbra 'live' during a stroke, especially late in its course, and therefore, giving us a tissue window. Three trials implied CT perfusion to look for the presence of a penumbra in patients presented between 6 and 24 hours of onset. If a mismatch was present and an LVO identified, IA thrombectomy was effective.

'Time is Brain' still reminds us that stroke is an emergency. However, tissue window has taught us that the treatment time window still exists in late presenters and we should not give up easily. While the time window is based on the witnessed time of a stroke that takes place, tissue window is the biological timing of an evolving ischaemia. Brain ischaemia is a dynamic process. Each patient may tolerate the ischaemia differently because of the difference in cerebral reserve, collateral circulation, size and completeness of an infarction. Study of ischaemia in rat middle cerebral artery occlusion model showed that even reperfusing the brain 14 days later, rats still had reasonable functional recovery. ${ }^{4}$ With the advent of new CT and MRI technology, we are now capable of accurately assessing such process. In fact, tissue window can not only identify opportunity for late presenters, but also guide us on treating early presenters. In clinical practice, we often see stroke patients with sizeable hypodense area on the initial CT of head although the witnessed time of onset was well within 3 hours. Alberta stroke program early CT (ASPECT) score was often used to decide if the risk of haemorrhagic transformation with reperfusion was high if ASPECT score was low, an indication of no penumbra was preset. Now, with the new imaging technology that can provide a tissue window, clinicians can make better judgement on treatment options for late presenters. ${ }^{5-7}$

Recently two published clinical trials have used MRI mismatch rather than CT perfusion mismatch to guide the use of IV tPA up to patients with AIS between 6 and 12 hours of onset and the outcome was positive. Both MRI-Guided Thrombolysis for Stroke with Unknown Time of Onset (WAKE-UP) and IV alteplase in MR-selected patients with stroke of unknown onset (MR WITNESS) trials used MRI diffusion weighted image/Fluid-attenuated inversion recovery (DWI/FLAIR) to look for the mismatch rather than a perfusion scan. ${ }^{89}$ In this issue of $S V N$, two centres in China reported their clinical experience on treating patients with AIS beyond 4.5 hours of time window. Both reports confirmed the findings from WAKE-UP and MR WITNESS trials. With a combined 600 patients treated from both trials, over 100 patients were actually treated beyond 12 hours. Furthermore, one centre actually used MRI DWI/T2-weighted image (T2WI) to look for the mismatch and reported to be successful. MRI DWI/T2W imaging was faster than FLAIR to acquire. . If MRI DWI/ T2WI is as good as DWI/PWI, the significance is that many small hospitals may not need to install software to interpret perfusion scans. Treatment with IV tPA can be offered faster.

In the near future, artificial intelligence may help assess the presence of a penumbra faster and with more precision. Furthermore, a perfusion scan or MRI/T2WI should be done regardless of the time of onset, be it within 3 hours or great than 24 hours onset, so that every patient 
with a stroke will have an accurate assessment of the tissue window, regardless of the time window.

Contributors All authors conceived, designed and drafted the study.

Funding The authors have not declared a specific grant for this research from any funding agency in the public, commercial or not-for-profit sectors.

Competing interests None declared.

Patient consent for publication Not required.

Provenance and peer review Commissioned; internally peer reviewed.

Open access This is an open access article distributed in accordance with the Creative Commons Attribution Non Commercial (CC BY-NC 4.0) license, which permits others to distribute, remix, adapt, build upon this work non-commercially, and license their derivative works on different terms, provided the original work is properly cited, appropriate credit is given, any changes made indicated, and the use is non-commercial. See: http://creativecommons.org/licenses/by-nc/4.0/.

\section{REFERENCES}

1. Hacke W, Kaste M, Bluhmki E, et al. Thrombolysis with alteplase 3 to 4.5 hours after acute ischemic stroke. N Engl $J$ Med 2008;359:1317-29.
2. Goyal M, Menon BK, van Zwam WH, et al. Endovascular thrombectomy after large-vessel ischaemic stroke: a meta-analysis of individual patient data from five randomised trials. The Lancet 2016;387:1723-31.

3. Powers WJ, Rabinstein AA, Ackerson T, et al. 2018 Guidelines for the early management of patients with acute ischemic stroke: A guideline for healthcare professionals from the American Heart Association/ American Stroke Association. Stroke 2018;49:e46-e99.

4. McBride DW, Wu G, Nowrangi D, et al. Delayed recanalization promotes functional recovery in rats following permanent middle cerebral artery occlusion. Trans/ Stroke Res 2018;9:185-98.

5. Nogueira RG, Jadhav AP, Haussen DC, et al. Thrombectomy 6 to 24 Hours after Stroke with a Mismatch between Deficit and Infarct. $N$ Engl J Med 2018;378:11-21.

6. Albers GW, Marks MP, Kemp S, et al. Thrombectomy for stroke at 6 to 16 hours with selection by perfusion imaging. $N$ Engl J Med 2018;378:708-18.

7. Lansberg MG, Christensen S, Kemp S, et al. Computed tomographic perfusion to predict response to recanalization in ischemic stroke. Ann Neurol 2017;81:849-56.

8. Schwamm LH, Wu O, Song SS, et al. Intravenous thrombolysis in unwitnessed stroke onset: MR WITNESS trial results. Ann Neurol 2018;83:980-93

9. Thomalla G, Simonsen CZ, Boutitie F, et al. MRI-Guided Thrombolysis for stroke with unknown time of onset. N Engl J Med 2018;379:611-22. 